\title{
Phytomass production and micronutrient cycling by cover crops in the Brazilian cerrado of Goias.
}

Leandro Pereira Pacheco', Weverson Lima Fonseca², Carlos César Evangelista de Menezes ${ }^{3}$, Wilson Mozena Leandro ${ }^{4}$, Renato Lara de Assis ${ }^{5}$, Fabiano André Petter ${ }^{6}$

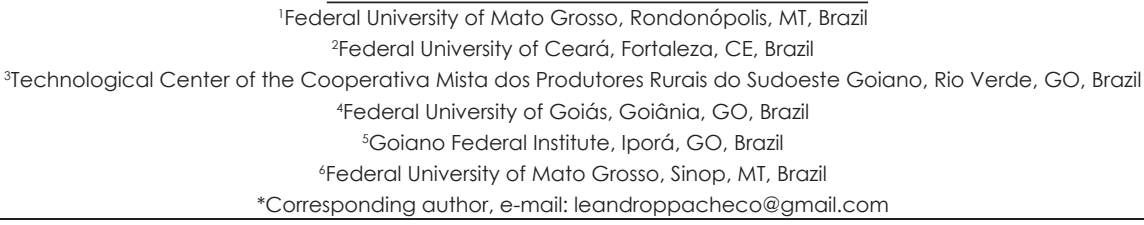

\begin{abstract}
The objective of this work was to evaluate the performance of cover crops over the phytomass production, accumulation and release of micronutrients in the Brazilian Cerrado of Goiás. The experiment was performed in Rio Verde, GO, Brazil, installed in dystroferric red latossol, from April 2008 to April 2009. The experimental design was a randomized block, in a factorial scheme $(4 \times 6)$, by split-splot array, with four replications. The plots received the cover crops, and the subplots consisted by biomass evaluations in six different times. The evaluated cover crops were: Urochloa ruziziensis, Pennisetum glaucum and U. ruziziensis + Cajanus Cajan and fallow area as reference. For the assessment of accumulation and release of biomass and micronutrients, biomass samples were collected in six times, from the management desiccation of the cover crops at the final off-season. The species U. ruziziensis and U. ruziziensis + C. cajan stood out in accumulation and in the release of biomass and micronutrients in the Brazilian Cerrado of Goiás.
\end{abstract}

Keywords: mulch, no-till, brachiaria, millet, pigeonpea

\section{Introduction}

The Cerrado region in Goiás state is an important grain production center in Brazil, with edaphoclimatic conditions favorable to the cultivation of annual crops. During the 2013/14 harvest, grain production was about 187 million tons (CONAB, 2014).The intensive soil use for production of annual crops in association with local climatic conditions results in soil degradation, mainly by intensification of erosion and compaction processes, modifying the physical, chemical and biological soil attributes (Prior et al., 2004; Aguiar \& Monteiro, 2005).

With this in mind, the adoption of technologies based in conservationist bases,

such as the use of cover crops, has become an essential strategy for the recovery and maintenance of soil quality (Azevedo et al., 2007). The direct planting system(DPS) emerges as a viable alternative for the sustainability of agricultural production, since it reduces erosion, adds and maintains organic matter in the soil, reduces infestation of spontaneous plants, and provides nutrient cycling (Pacheco et al., 2008; Pacheco et al. 2013).

The use of cover crops can restore considerable amounts of nutrients to crops, since these plants absorb nutrients in the subsurface layers of the soil and release them later into the surface layer by decomposing their residues 
(Torres et al., 2008). The availability of nutrients from these plant residues can be fast and intense, depending on climatic factors interaction and their chemical nature (Rosolem et al., 2003).

The millet (Pennisetum glaucum) is a species widely used as a cover crop because of its rapid growth, high phytomass production and ability to absorb nutrients in deeper layers of soil, even when managed under conditions of water restriction (Pacheco et al. , 2011 a). In addition, according to Crusciol \& Soratto (2009), millet is species with high soil nutrient extraction capacity, with large recycling advantages, mainly $\mathrm{N}$ and $\mathrm{K}$, reducing the risk of leaching. Urochloa ruziziensis presents satisfactory characteristics when used for soil cover purposes, presenting adequate shoot growth, high root numbers and resistance to unfavorable conditions, such as low fertility soils and long drought periods (Giancotti et al., 2010). The consortium of Urochloa species with leguminous semi-perennial plants as the guandu bean (Cajanus cajan) can result in the phytomass (Amabile et al., 2000) and nitrogen increment in the soil by biologic fixation (Henriksen et al., 2002).

This work is justified once the studies on micronutrient cycling in agricultural systems, especially the insertion of upland rice cultivation into productive systems using DPS, are limitating (Pacheco et al., 2011b). Studies have shown that the availability of nutrients in the soil, with emphasis on the lower levels of nitrogen in the ammoniacal form, may limit the initial growth and development of rice in direct planting due to the low activity of the nitrate reductase enzyme (Kluthcouski et al., 2000).

The researches highlights that one of the possible limiting factors is also the insufficient initial availability of some micronutrients, such as zinc. In this respect, the selection of cover crops with the potential to accumulate and restore considerable amounts of micronutrients to the soil can make possible to include upland rice cultivation to rotation of crops in the Cerrado of Goiás.

The objective of this work was to evaluate the performance of cover crops in relation to accumulation and release of micronutrients in different systems of soil preparation in the Cerrado of Goiás.

\section{Material and Methods}

The experiment was installed in Rio Verde, GO, at the Technological Center of the Cooperativa Mista dos Produtores Rurais do Sudoeste Goiano - COMIGO, from April 2008 to April 2009, in a dystroferric Red Latosol (Embrapa, 1999) during $2007 / 08$ and 2008/09 harvests. The soil presented the following characteristics at the time of experiment installation, in the layer of 0 to $20 \mathrm{~cm}$ : 420; 110; $470 \mathrm{~g} \mathrm{~kg}^{-1}$ of clay, silt and sand, respectively; $\mathrm{pH} 4.7\left(\mathrm{CaCl}_{2}\right) ; 4.2 \mathrm{mg} \mathrm{kg}^{-1}$ of $\mathrm{P}$ (Mehlich-1); $58.1 \mathrm{mg} \mathrm{dm}^{-3} \mathrm{~K} ; 1.9{\mathrm{cmolc} \mathrm{dm}^{-3}}^{-3}$ $\mathrm{Ca}^{2+} ; 0.4 \mathrm{cmolc} \mathrm{dm}^{-3} \mathrm{Mg}^{2+} ; 4.7 \mathrm{cmolc} \mathrm{dm}^{-3} \mathrm{H}+\mathrm{Al}$; $29.0 \mathrm{~g} \mathrm{~kg}^{-1}$ of organic matter; $7.1 \mathrm{cmolc} \mathrm{dm}^{-3}$ of CTC; and $35 \%$ of $\mathrm{V}$. In the two previous harvests, 2005/06 and 2006/07, the area was cultivated with soybean in the summer and millet in the "safrinha" period using the direct planting system (DPS). The climate of the experimental area, according to Köppen classification, is Cwa type (altitude of $770 \mathrm{~m}$ ).

The experimental design was a randomized complete block, with a layout of subdivided plots $(4 \times 6)$, four replications, with the cover plants allocated to the plots, and the evaluation periods in the subplots (six sampling of phytomass after desiccation for sowing rice). Urochloa ruziziensis $\left(10 \mathrm{~kg} \mathrm{ha}^{-1}\right.$ of seeds with cultural value - $\mathrm{CV}=70 \%)$, Pennisetum glaucum (millet ADR300 - $13 \mathrm{~kg} \mathrm{ha}^{-1}$ ) and U. ruziziensis + Cajanus cajan (5+10 kg ha-1, respectively). In the fallow treatment there was predominance of timbete grass (Cenchrus echinatus). The cover plants were sown manually, with $0.45 \mathrm{~m}$ spacing between rows, without fertilizer use, immediately after the 2007/08 soybean harvest in DPS (10/04/2008). The dimensions of each plot consisted of $5 \times 10 \mathrm{~m}$.

At the beginning of the 2008/09 harvest, October 13, 2008, all the cover plants were desiccated. After 30 days, the second desiccation was carried out using glyphosate herbicide (1,468 $\mathrm{kg} \mathrm{ha}^{-1}$ acid equivalent) and Paraquat (400 $\mathrm{g} \mathrm{ha}^{-1}$ active ingredient), to be used to sow the 2008/09 crop rice in DPS. Then, the highland rice was sown in DPS, cultivar BRS Sertaneja, with $0.45 \mathrm{~m}$ spacing, with 85 seeds per meter and fertilization in the sowing furrow of 300 
$\mathrm{kg} \mathrm{ha}^{-1}$ of the 8-20-18 NPK formulation. Coverage fertilization with $N$ was performed at 40 DAS of the rice, with $60 \mathrm{~kg} \mathrm{ha}^{-1}$ of $\mathrm{N}$ in the urea-form, applied to haul on the soil surface.

The P. glaucum plots were desiccated with glyphosate $\left(1,468 \mathrm{~kg} \mathrm{ha}^{-1}\right.$ acid equivalent) when they were in full flowering stage, on $06 / 12 / 2008$, in an attempt to avoid translocation of photoassimilates to the grains and to maximize the production of phytomass in the system with this species. For the evaluation of the dry matter, soil cover and nutrients remaining of the cover plants, the plots were subdivided in time, constituting six evaluation periods: $0,15,30,60,90$ and 120 days after the desiccation management date (DMD) of the cover crops for the rice sowing (10/13/2008).

The dry matter of the cover plants was evaluated in all subplots, according to method proposed by Crusciol et al. (2005), which consists on the use of iron square with dimensions of $0.5 \mathrm{x}$ $0.5 \mathrm{~m}\left(0.25 \mathrm{~m}^{2}\right)$, in which the aerial part (shoots) and residues of the cover plants were collected, with two replications per subplot. Afterwards, they were dried in a $60^{\circ} \mathrm{C}$, during 3 days, after which the residue was washed manually without using water to obtain the dry matter. These residues were ground in a Wiley mill $(2 \mathrm{~mm})$ for further determination of $\mathrm{B}, \mathrm{Mn}, \mathrm{Zn}$ and $\mathrm{Cu}$ contents following the method proposed by Nogueira et al. (2005). To determine the $\mathrm{C} / \mathrm{N}$ ratio at the time of cover crop management desiccation, the total $\mathrm{C}$ content in the vegetable tissues was quantified by colorimetric method (Cantarella et al., 2001).

In order to describe the release of dry matter and nutrients in the cover plants, the data was adjusted to an exponential mathematical model, described by Wieder \& Lang (1982): PL = Po exp $(-k t)$; where PL is the amount of dry matter and nutrients $\left(\mathrm{kg} \mathrm{ha}^{-1}\right)$ at time $\dagger$ (days); Po is the fraction of dry matter and nutrients potentially released $\left(\mathrm{kg} \mathrm{ha}^{-1}\right)$; and $\mathrm{k}$ is the rate of nutrients release $\left(\mathrm{g} \mathrm{g}^{-1}\right)$. With the $k$ value, the half-life time $\left(t \frac{1}{2}\right)$ of the dry matter and the remaining nutrients were calculated using the formula $t^{1} / 2=0.693 / k$, proposed by Paul \& Clark (1996).

The results were submitted to analysis of variance and the qualitative means, compared by the Tukey test at $5 \%$. The regression equations used in the quantitative data were obtained with the aid of Sigma Plot software, version 10.0.

\section{Results and discussion}

The results showed that the cover plants presented significant effects on dry matter production (DMP) and accumulated nutrient contents (B, Zn, Mn and Cu) (Table 1).

Table 1. Analysis of variance ( $p$ values) for phytomass and micronutrients accumulated by cover and fallow plants, em Rio Verde, GO.

\begin{tabular}{cccccc}
\hline Variation sources & Phytomass & Boron & Zinc & Manganese & Copper \\
\hline Crop plants (CP) & $102.13^{* *}$ & $742.38^{* *}$ & $1063.81^{* *}$ & $1016.18^{* *}$ & $476.96^{* *}$ \\
Sampling time (ST) & $123.18^{* *}$ & $449.75^{* *}$ & $849.89^{* *}$ & $613.19^{* *}$ & $1188.70^{* *}$ \\
\hline CP $(1) \times$ ST (2) & $4.84^{* *}$ & $10.90^{* *}$ & $29.51^{* *}$ & $28.90^{* *}$ & $26.74^{* *}$ \\
\hline *and ** Significant to 5 and 1\% of probability & & & & &
\end{tabular}

At the desiccation management date (O DMD), the use of the species U. ruziziensis and the consortium U. ruziziensis $+C$. cajan presented higher production of DPM and micronutrients (Table 2). The monoculture with U. ruziziensis produced values close to $5 \mathrm{th}^{-1}$ for DPM, since in a consortium with $C$. cajan it allowed a moderate increment of DPM reaching about 5.4 t ha ${ }^{-1}$. Similar results were found by Pacheco et al., (2012), who in the same Cerrado conditions found DPM on the order of $4.8+\mathrm{ha}^{-1}$ (U. ruziziensis and C. cajan). Superior results when compared with this work were found by Menezes \& Leandro (2004), with $6.9+\mathrm{ha}^{-1}$ (U. ruziziensis) at 180 days after sowing. These results are related to the high resistance to water stress during off-season and the regrowth / germination of the U. ruziziensis species after the resumption of summer rains.

Pennisetum glaucum showed the lowest DPM accumulation, reaching about $2.3+\mathrm{ha}^{-1}$ (table 2). Pacheco et al. (2012) found similar results with a mean of $2.0 \mathrm{tha}^{-1}$ of DPM at 180 days after sowing. Superior results were found by Boer et al. (2007) with $10.1+$ ha $^{-1}$ of DPM. The lowest DPM production occurred due to $P$. glaucum being 
desiccated at the full flowering stage, which occurred during the off-season (June / 2008). In this way, the mineralization of the vegetal tissues began in advance to other cover plants, which reduced the amount of straw on the soil surface at the beginning of the next harvest.

The desiccation was carried out in $P$. glaucum during the flowering phase, as an attempt to avoid the loss of DPM by the process of grain filling. However, in considering the early initiation of mineralization in relation to sowing of the next crop, this process seems to have impaired the presence of straw on the soil surface.

The spontaneous vegetation cover (fallow), even providing higher mean values for DPM (about $3+\mathrm{ha}^{-1}$ ), compared to $P$. glaucum, did not reach the ideal amount from a soil conservationist point of view. According to Menezes et al. (2009), requires at least 5 t ha- $^{-1}$ of DPM to maintain a satisfactory amount of soil cover throughout the agricultural year.

The decomposition rate of the plant phytomass deposited on the soil is directly related to the carbon / nitrogen ratio ( $\mathrm{C} / \mathrm{N}$ ). During the evaluation period, the highest $C / N$ ratios in the DPM were verified in P. glaucum and in the consortium U. ruziziensis + C. cajan obtaining, respectively, 70 and 40 (Table 3). Carpim et al. (2008) found distinct values of $C / N$ ratio of 18,19 and 22 / 1 for $P$. glaucum cultivar ADR 300 in the Cerrado of southwestern Goiás, in the pre-rubber, pre-flowering and early phenological stages. For P. glaucum this fact can be explained due the plant rapidly reach the flowering stage at 60 DAS, in which, after the management desiccation, the decomposition of its cultural residues began with significant release of $\mathrm{N}$, and high levels of lignin and cellulose, which are organic compounds of difficult decomposition, being more resistant to the action of microorganisms (Boer et al., 2007).

Tabele 2. Phytomass and micronutrients accumulated by cover crops at diseccation time in the 2008/2009 harvest season, in Rio Verde, GO (1).

\begin{tabular}{cccccc}
\hline Crop plants & Dry phytomass & Boron & Zinc & Manganese & Copper \\
\hline & $\mathrm{Kg} \mathrm{ha}^{-1}$ & \multicolumn{4}{c}{$\mathrm{g} \mathrm{ha}^{-1}$} \\
UR $^{(2)}$ & $4827 \mathrm{a}$ & $529.92 \mathrm{~b}$ & $93.85 \mathrm{~b}$ & $337.22 \mathrm{~b}$ & $39.79 \mathrm{~b}$ \\
$\mathrm{PG}^{(3)}$ & $2307 \mathrm{~b}$ & $272.44 \mathrm{~d}$ & $46.26 \mathrm{~d}$ & $138.24 \mathrm{~d}$ & $24.07 \mathrm{~d}$ \\
$\mathrm{UR}+\mathrm{CC}^{(4)}$ & $5333 \mathrm{a}$ & $644.38 \mathrm{a}$ & $106.50 \mathrm{a}$ & $425.47 \mathrm{a}$ & $43.97 \mathrm{a}$ \\
$\mathrm{F}^{(5)}$ & $3035 \mathrm{~b}$ & $416.63 \mathrm{C}$ & $55.92 \mathrm{C}$ & $273.39 \mathrm{C}$ & $27.35 \mathrm{C}$ \\
\hline VC (\%) & 14.96 & 7.22 & 6.21 & 6.43 & 5.95 \\
DMS & 737.79 & 39.47 & 5.17 & 22.86 & 2.20 \\
\hline (1) Means followed by equal letters in the columns do not differ from each other by the Tukey test at 5\% probability. (2) Uruchoa ruzizienses; (3) Pennisetun glaucum;
\end{tabular}

Table 3. Phytomass C/N ratio of cover crops at desiccation management datein the 2008/09 harvest, in Rio Verde, GO(1).

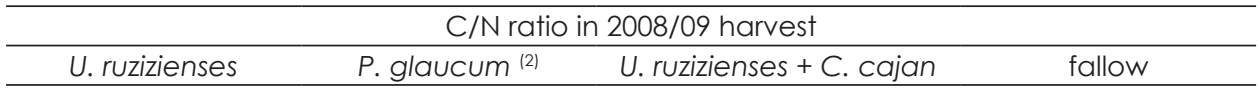

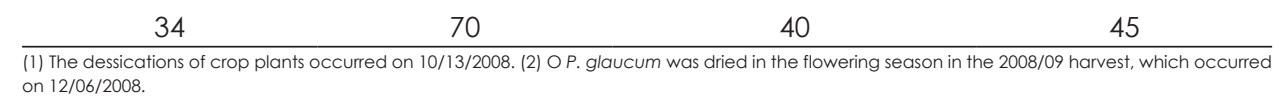

After the desiccation of cover crop management, the cultural remains deposited on the soil surface began to decompose (Figure 1). The highest FS decomposition rates in most of the evaluated epochs were found in U. ruziziensis and $U$. ruziziensis + C. cajan, showing already at 30 days after DMD decomposition rates of $20.14 \%$ and $24.30 \%$, respectively .

The fallow presented a slower rate of decomposition in relation to the other treatments (Figure 1), due to the fact that its DPM had a significant presence of fractions with an advanced decomposition stage (C / $\mathrm{N}$ ratio of 45 , Table 3 ), originated from spontaneous plants that emerged and senesced in the off-season, due to the interruption of rains.

For micronutrient accumulation in the DPMof the cover plants, it was observed that at desiccation management date (O DMD), the consortium $U$. ruziziensis $+C$. cajan presented the highest accumulations of $\mathrm{B}, \mathrm{Zn}, \mathrm{Mn}$ and $\mathrm{Cu}$ (table 2). These results are related to the higher DPM 

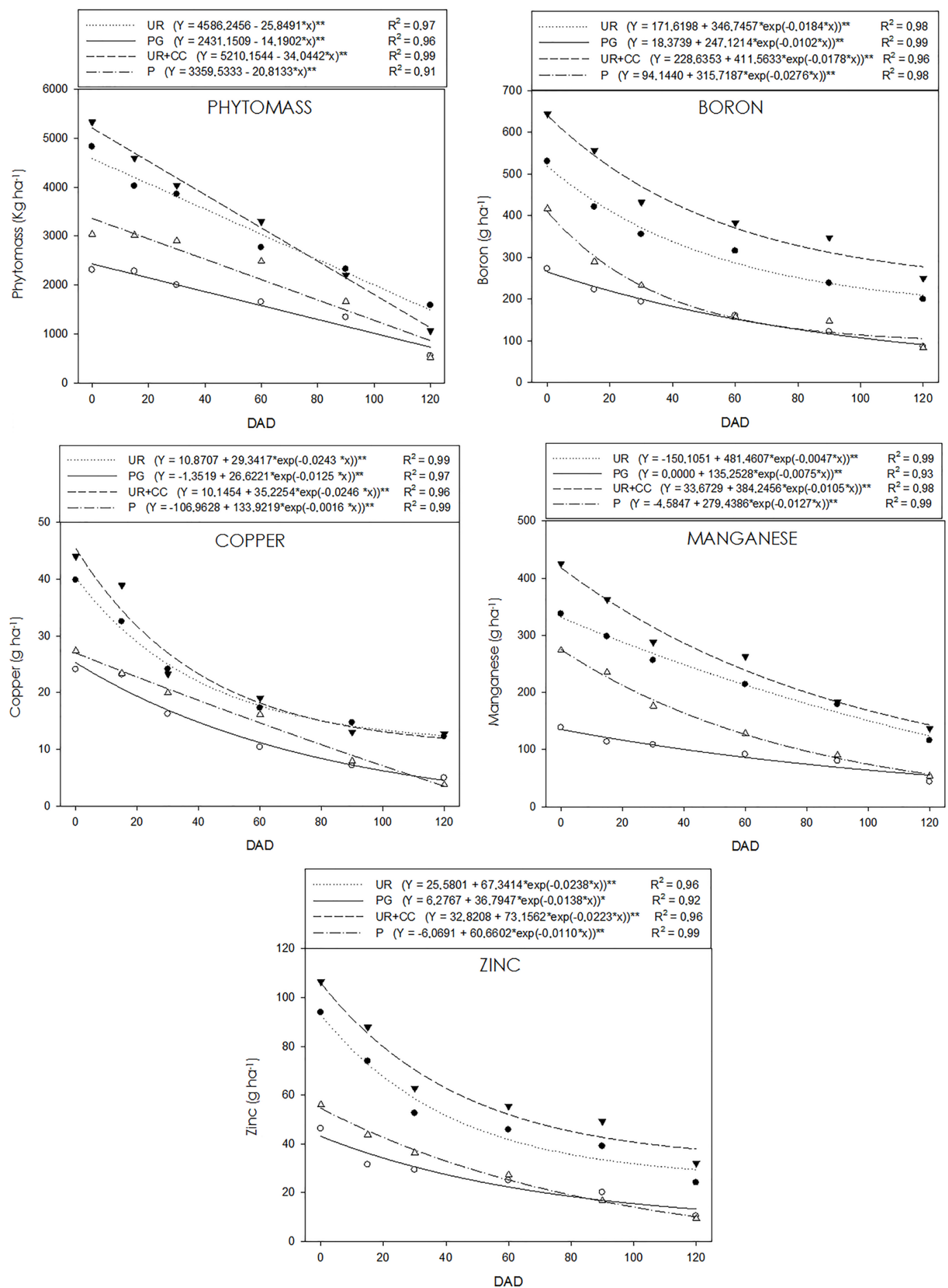

Figure 1. Regression analysis for phytomass decomposition and micronutrient release by cover crops, during the 2008/2009 harvest, evaluated in six dates after desiccation management date (DMD), in Rio Verde, GO. * and ** significant to $5 \%$ and $1 \%$ of probability.

productivity of the aerial part obtained by $U$. ruziziensis + C. cajan. In a study by Cazetta et al. (2005) evaluating the levels of zinc in Crotalaria and $P$. glaucum, it was verified a higher content of this nutrient in $P$. glaucum plants. Already Teixeira et al. (2008) evaluating P. glaucum at 119 days after planting, observed the accumulation of 27, 280 and $289 \mathrm{~g} \mathrm{ha}^{-1}$ of $\mathrm{Cu}, \mathrm{Zn}$ and $\mathrm{Mn}$, respectively, for a DPM production of $2.9 \mathrm{tha}^{-1}$. In other research, Oliveira et al. (2002) observed accumulations of $\mathrm{Zn}, \mathrm{Cu}$ and $\mathrm{Mn}$, respectively, with 292, 70 and $1409 \mathrm{~g} \mathrm{ha}^{-1}$ in P. glaucum and 279, 102 and $922 \mathrm{~g} \mathrm{ha}^{-1}$ of $\mathrm{Zn}, \mathrm{Cu}$ and $\mathrm{Mn}$, respectively, in sorghum when evaluated at 100 days after planting in Lavras, MG.

When the nutrient release rate was 
analyzed in the cover residues species, U. ruziziensis and the $U$. ruziziensis + C. cajan consortium, they presented the highest rates, which can be attested by the shorter half-life times, except for manganese (Table 4). The regression analysis showed that the cover plants presented a linear behavior for the DPM decomposition (Figure 1). As for the release of micronutrients, the cover plants adjusted themselves according to exponential relation. This behavior can be explained by the high rate of decomposition and mineralization of DPM occurring just after the management desiccation. When observing the half-life of the micronutrients, it was observed that zinc and copper had the highest release rates, and a half of these nutrients were released by cover plants at 29 days. On the other hand, the micronutrients boron and manganese had the lowest release rate, which may be related to the minor solubility of these nutrients in water.

Table 4. Half-life time in days for micronutrients of cover crops in the crop 2008/09, in Rio Verde, GO(1).

\begin{tabular}{ccccc}
\hline & U. ruzizienses & P. glaucum ${ }^{(2)}$ & U. ruzizienses + C. Cajan & fallow \\
\hline Boron & 38 & 68 & 39 & 25 \\
Zinc & 29 & 50 & 31 & 63 \\
Manganese & 173 & 92 & 66 & 55 \\
Copper & 29 & 55 & 28 & 433 \\
\hline (1) The cover crops desiccations occurred in 13/10/2008. (2) The P. glaucum was desiccated during the flowering phase in the crop 2008/09, which occurred in
\end{tabular}

12/06/2008.

\section{Conclusions}

The species U. ruziziensis and U. ruziziensis + C. cajan stand out in the phytomass production and accumulation of micronutrients at the end of the off-season.

Boron was the most accumulated micronutrient by the cover, while copper and zinc presented the highest release rates to soil.

The highest rates of dry matter decomposition in most of the evaluated times were found in both $U$. ruziziensis and U. ruziziensis + C. cajan.

The species U. ruziziensis and U. ruziziensis + C. cajan provided the highest release rates of micronutrients to soil.

\section{Acknowledgements}

To the Cooperativa Mista dos Produtores Rurais do Sudoeste Goiano - COMIGO for the financial and technical supports; To the Agrisus Foundation for financial support; And to CAPES and $\mathrm{CNPq}$ for scholarships granted to the postgraduate student and the fellowship of research productivity (PQ), respectively.

\section{References}

Aguiar, T.J.A., Monteiro, M.S.L. 2005. Modelo agrícola e desenvolvimento sustentável: a ocupação do Cerrado piauiense. Ambiente e Sociedade 8: 1-18.

Amabile, R.F., Fancelli, A.L., Carvalho, A.M. 2000. Comportamento de espécies de adubos verdes em diferentes épocas de semeadura e espaçamentos na região dos Cerrados. Pesquisa Agropecuária Brasileira 35: 47-54.

Azevedo, D.M.P., Leite, L.F.C., Teixeira Neto, M.L., Dantas, J.S. 2007. Atributos físicos e químicos de um Latossolo Amarelo e distribuição do sistema radicular da soja sob diferentes sistemas de preparo no Cerrado maranhense. Revista Ciência Agronômica 38: 32-40.

Boer, C.A., Assis, R.L., Silva, G.P., Braz, A.J.B.P., Barroso, A.L.L., Cargnelutti filho, A., Pires, F.R. 2007. Ciclagem de nutrientes por plantas de cobertura na entressafra em um solo de Cerrado. Pesquisa Agropecuária Brasileira 42: 1269-1276.

Cantarella, H., Quaggio, H.C., Raij, B.van. 2001. Determinação da matéria orgânica. In: RAIJ, B.van, Andrade, J.C., Canterella, H., Quaggio, J.A., eds. Análise química para avaliação da fertilidade de solos tropicais. Instituto Agronômico de Campinas, Campinas, Brazil. p.173-188.

Carpim, L., Assis, R.L., Braz, A.J.B.P., Silva, G.P., Pires, F.R., Pereira, V.C., Gomes, G.V., Silva, A.G. 2008. Liberação de nutrientes pela palhada de milheto em diferentes estádios fenológicos. Revista Brasileira de Ciência do Solo 32: 28132819.

CONAB - Companhia Nacional de Abastecimento. $12^{\circ}$ Levantamento da Produção de Grãos - Safra 2013/14. Brasília: CONAB, 2013. Disponível em:< http:// wWw.conab.gov.br/OlalaCMS/uploads/ arquivos/14_10_23_10_20_02_boletim_graos_ outubro_2014.pdf $>$.

Crusciol, C.A.C., Cottica, R.L., Lima, E.V., Andreotti, M., Moro, E., Marcon, E. 2005. 
Persistência de palhada e liberação de nutrientes do nabo forrageiro no plantio direto. Pesquisa Agropecuária Brasileira 40: 161-168.

Crusciol, C.A.C., Soratto, R.P. 2009. Nitrogen supply for cover crops and effects on peanut grown in succession under a no-till system. Agronomy Journal 101: 41-46.

Giancotti, P.R.F., Nepomuceno, M., Yamauti, M.S., Colmanetti M.A., Guzzo, C.D., Alves, P.L.C.A. 2010. Épocas de manejo de Bracearia ruziziensis antecedendo o plantio direto do girassol. In: XXVII Congresso Brasileiro da Ciência das Plantas. Anais... Ribeirão Preto, Brazil.

Henriksen, I., Michelsen, A., Schlonvoigt, A. 2002. Tree species selection and soil tillage in alley cropping systems with Phaseolus vulgaris L. in a humid premontane climate: biomass production, nutrient cycling and crop responses. Plant and Soil 240: 145-159.

Kluthcouski, J., Fancelli, A.L., Dourado-Neto, D., Ribeiro, C.R., Ferraro, A. 2000. Manejo do solo e o rendimento de soja, milho, feijão e arroz em plantio direto. Scientia Agricola, 57:97-104.

Menezes, L.A.S., Leandro, W.M. 2004. Avaliação de espécies de coberturas do solo com potencial de uso em sistema de plantio direto. Pesquisa Agropecuária Tropical 34: 173-180.

Menezes, L.A.S., Leandro, W.M., Oliveira Junior, J.P., Ferreira, A.C.B., Santana, J.G., Barros, R.G. 2009. Produção de fitomassa de diferentes espécies, isoladas e consorciadas, com potencial de utilização para cobertura do solo. Bioscience Journal 25: 7-12.

Moreti, D., Alves, M.C., Valério Filho, W.V., Carvalho, M.P. 2007. Atributos químicos de um Latossolo Vermelho sob diferentes sistemas de preparo, adubações e plantas de cobertura. Revista Brasileira de Ciência do Solo 31: 167-175.

Pacheco, L.P., Leandro, W.M., Machado, P.L.O.A., Assis, R.L., Cobucci, P., Madari, B.E., Petter, F.A. 2011 (a). Produção de fitomassa e acúmulo e liberação de nutrientes por plantas de cobertura na safrinha. Pesquisa Agropecuária Brasileira, Brasilia 46: 17-25.

Pacheco, L.P., Monteiro, M.M.S., Silva, R.F., Soares, L.S., Fonseca, W.L., Nóbrega, J.C.A., Petter, F.A., Neto, F.A., Osajima, J.A. 2013. Produção de fitomassa e acúmulo de nutrientes por plantas de cobertura no Cerrado piaviense. Bragantia 72: 237-246.

Pacheco, L.P., Pires, F.R., Monteiro, F.P., Procopio, S.O., Assis, R.L., Carmo, M.L. Petter, F.A. 2008. Desempenho de plantas de cobertura em sobressemeadura na cultura da soja. Pesquisa Agropecuária Brasileira 43: 815-823.
Pacheco, L.P., Barbosa, J.M., Leandro, W.M., Machado, P.L.O.A., Assis, R.L., Madari, B.E., Petter, F.A. 2011 (b). Produção e ciclagem de nutrientes por plantas de cobertura nas culturas de arroz de terras altas e de soja. Revista Brasileira de Ciência do Solo 35: 1787-1799.

Paul, E.A. \& Clark, F.E. 1996. Dynamics of residue decomposition and soil organic matter turnover. In: Paul, E.A. \& Clark, F.E., eds. Soil microbiology and biochemistry. 2.ed. San Diego, Academic. p.158-179.

Prior, S.A., Torbert, H.A., Runion, G.B., \& Rogers, H. (2004). Elevated atmospheric CO2 in Agroecosystems: residue decomposition in the field. Environmental Management 33: 344-354.

Rosolem, C.A., Calonego, J.C., Foloni, J.S.S. 2003. Lixiviação do potássio da palhada de espécies de cobertura de solo de acordo com a quantidade de chuva aplicada. Revista Brasileira de Ciências do Solo 27: 355-362.

Silva, T.O., Neto, A.E.F., Carneiro, L.F., Paludo, V. 2011. Plantas de cobertura submetidas a diferentes fontes de fósforo em solos distintos. Ciências Agrárias, Londrina 32: 1315-1326.

Sodré Filho, J., Cardoso, A.N., Carmoral, R., Carvalho, A.M. 2004. Fitomassa e cobertura do solo de culturas de sucessão ao milho na Região do Cerrado. Pesquisa Agropecuária Brasileira 39: 327-334.

Torres, J.L.R., Pereira, M.G., Fabian, A.J. 2008. Produção de fitomassa por plantas de cobertura e mineralização de seus resíduos em plantio direto. Pesquisa Agropecuária Brasileira, Brasília 43: 421-428.

Wieder, R.K. \& Lang, G.E. 1982. A critique of the anylitical methods used in examining decomposition data obtained from litter bags. Ecology 63: 1636-1642.

Teixeira, C.M., Carvalho, G.J., Andrade, M.J.B., Furtini Neto, A.E. 2008. Biomassa, teor e acúmulo de micronutrientes do milheto, feijão-de porco e guandu-anão, em cultivo solteiro e consorciado. Acta Scientiarum Agronomy 30: 533-538.

Cazetta, D.A., Fornasieri Filho, D., Girotto, F. 2005. Composição, produção de matéria seca e cobertura do solo em cultivo exclusivo e consorciado de milheto e crotalária. Acta Scientiarum Agronomy 27: 575-580.

Oliveira, T.K. Carvalho, G.J., Moraes, R.N.S. 2002. Plantas de cobertura e seus efeitos sobre 0 feijoeiro em plantio direto. Pesquisa Agropecuária Brasileira 37: 1079-1087. 